\title{
The Effect of Sour Milk as a Postmilking Teat Dip for Mastitis Prevention in a Dairy Herd
}

\author{
By E. Koskinen ${ }^{1}$, M. Rantala ${ }^{2}$ and H. Saloniemi ${ }^{3}$ \\ ${ }^{1}$ Agricultural Research Centre, Jokioinen, ${ }^{2}$ Municipal Food Control Laboratory, Kemijärvi, and ${ }^{3}$ Faculty of Vet- \\ erinary Medicine, University of Helsinki, Finland.
}

\begin{abstract}
Koskinen, E., M. Rantala and H. Saloniemi: The effect of sour milk as a postmilking teat dip on somatic cell count and bacterial growth in a dairy herd. Acta vet. scand. 1996, 37, 427-432. - In a preliminary in vitro study, the growth of Staphylococcus aureus was totally inhibited during incubation for $24 \mathrm{~h}$ at $35^{\circ} \mathrm{C}-37^{\circ} \mathrm{C}$ in a solution of cooked commercial milk with $1 \%$ of uncooked commercial sour mılk ("A piimä"). In a subsequent clınıcal trial, "A pımä" sour milk with $5 \%$ glycerol was used as a postmilking teat dip from February to June. Quarterly milk samples were drawn once a month aseptically from 133 cows. Percentages of pathogen positive samples and somatic cell count (SCC) from teats dipped with the sour milk were compared with those dipped with a commercial iodine teat dip and those of undipped controls. During March-June there were fewer isolations of $S$. aureus $(2.09 \%)$ and coagulase-negative staphylococc1 $(2.52 \%)$ in the sour-milk group than in the control group $(3.09 \%$ and $4.07 \%$, respectively). In iodine group, there were fewer 1solations of $S$. aureus $(0.83 \%)$ but more isolations of coagulase-negative staphylococc1 (5.26\%) than in the control group. During the study period, the percentages of bacterial isolates did not differ statistically significantly between treatments, $p=0.291$. The percentage of quarters with a SCC over 125,000 at the end of the study was one third lower in the sour-milk group than in the control group ( $16.67 \%$ and $26.23 \%$ respectively) but the difference was not statıstically sıgnificant $(p=0.074)$. The results indicate that a sour-milk teat-dip preparation can inhibit new intra mammary infections (IMI).
\end{abstract}

Lactobacillus acidophilus; SCC; IMI; bovine.

\section{Introduction}

Numerous post-dipping studies have been presented where different formulations are described to reduce the rate of bovine mastitis (Pankey 1992). However, one limiting factor in the use of many formulations is the risk of residues in milk. Woodward et al. (1987) have reported that approximately $25 \%$ of the isolates of normal flora recovered from the teat ends of healthy heifers inhibit in vitro the growth of Gram-positive and Gram-negative udder pathogens. They suggested that colonization of teat ends with normal flora inhibiting pathogens in vitro may increase nonspecific resistance to mastitis. Lactobacillus acidophilus has been reported to exert antagonistic actions on growth of Staphylococcus aureus among other pathogens when grown with each in associative cultures (Gilliland \& Speck 1977). We could find no published data on the effect of dipping the teats of milking cows with solutions containing lactic acid bacteria to inhibit new intra mammary infections (IMI).

In the 2 studies reported here, we first examined the ability of one lactobacillus culture and 5 
sour milk products (cooked and uncooked) to inhibit the in vitro growth of Staphylococcus aureus, an important cause of acute and chronic bovine mastitis. In a subsequent clinical trial we used the most effective sour milk product from the in vitro study as a postmilking teat dip. Percentages of bacteria positive milk samples and somatic cell count (SCC) in quarter milk samples from these quarters were compared with those from teats dipped with a commercial iodine teat dip, and from undipped controls.

\section{Materials and methods}

The $S$. aureus strains used in the in vitro study were isolated from clinical cases of mastitis at Kemijärvi region. The growth of inocula of $10-100$ cells of $S$. aureus $\left(0.1 \mathrm{ml}\right.$ of a $10^{-7}$ dilution of a $S$. aureus bouillon culture incubated for $24 \mathrm{~h}$ at $37^{\circ} \mathrm{C}$ ) was examined in tubes containing $9.9 \mathrm{ml}$ of cooked, commercial milk. To these tubes were added $0.1 \mathrm{ml}$ of one of the following sour milk products: uncooked or cooked commercial Finnish sour milk "A piimä”, or uncooked or cooked commercial Finnish sour milk "Gefilus", or commercial Finnish buttermilk "Kirnupiimä”, or a Lactobacillus spp. culture made of lyophilized bacteria (Laboratoires Lyocentre, France) incubated for $24 \mathrm{~h}$ at $39^{\circ} \mathrm{C}$ in cooked milk. The trial was repeated once with "A piimä" sour milk. "A piimä” sour milk included the following lactic acid bacteria: $L$. acidophilus, Lactococcus lactis ssp. lactis and cremoris, Lactococcus lactis ssp. lactis var. diacetylactis, and Leuconostoc mesenteroides ssp. cremoris. "Gefilus" included the same bacteria as "A piimä" and Lactobacillus GG. Tubes were incubated for $24 \mathrm{~h}$ at $35^{\circ} \mathrm{C}-37^{\circ} \mathrm{C}$ and then sub-cultured on bovine blood agar plates and Baird Parker agar plates.

After the in vitro study, a clinical trial was conducted at the Agricultural Research Centre in Finland. The animals were kept in 3 cowhouses with, on average, 60 cows in each. The animals were of ayshire breed, they were on average 3.8 years $( \pm 1.5 \mathrm{SD})$ old and they had been lactating on average for 3.2 months ( $\pm 2.1 \mathrm{SD}$ ) at the beginning of the study. Initial quarter milk samples were collected in February 1993. Based on these samples the animals were put to groups on the basis of general udder health, in terms of the highest SCC in any quarter. SCC limits were $125,000,250,000$ and $1,500,000$. The treatment subject in the study was udder half. Within the cow groups, udder halves were assigned at random to: no treatment, dipping with “A piimä" sour milk, including 5\% of glycerol to prevent drying of the teat skin, or dipping with a commercial iodine dip (Tehotippi, Orion-Farmos OY, Finland: iodine concentration after dilution for use is $0.15 \%$ ). The experimental design was incomplete block design with 2 treatment subjects (left and right udder halves) and 3 treatments (SAS Proc plan, SAS Institute Inc., Cary, NC, USA). Because udder halves were assigned at random to treatment groups, the distribution of age, lactation phase, cowhouse, management and related factors were similar in all treatment groups. Dipping was started 5 or 6 days after the initial milk samples had been collected. Two to 5 centimeters of a teat were dipped. Quarter milk samples were collected aseptically before milking in the morning, once a month, from March to June. After milking, the samples were put in a refrigerator. SCC was measured within $6 \mathrm{~h}$ after milking. Cells were counted using an automatic cell counter (Fossomatic). Before counting of cells, milk samples were warmed to $40^{\circ} \mathrm{C}$. The rest of the milk sample was frozen at $-20^{\circ} \mathrm{C}$ and sent for bacterial examination. Only pathogenic bacteria were examined. $S$. aureus, coagulasenegative staphylococcus (CNS), Streptococcus agalactiae, Streptococcus dysgalactiae, Streptococcus uberis, Enterococcus faecalis and faecium, Actinomyces pyogenes, Corynebacterium 
bovis, Escherichia coli and Klebsiella were identıfied according to Honkanen-Buzalski \& Seuna (1995). One or more colonies of bacteria on an agar plate was considered as an indication of bacteria positive sample in this study. There were $12.1 \%$ of milk samples with less than 5 colonies on agar plate of all bacteria positive milk samples. Before the beginning of the study, other changes had been made to milking practices; e.g. milkers had began to use disposable milking cloths. The changes were similar in all treatment groups.

McNemar's test for correlated proportions was used to determine the significance of change in percentages of bacterial isolations from February to March. The chi-squared test was used to determine whether treatments had significant effects on percentages of bacterial isolations overall during treatment, or on percentages of quarters with SCC $>125,000$ at the end of the study.

\section{Results}

\section{In vitro study}

$S$. aureus growth was totally inhibited by one per cent of uncooked commercial sour milk "A piimä" during incubation at $35^{\circ} \mathrm{C}-37^{\circ} \mathrm{C}$ for 24 $\mathrm{h}$ in cooked commercial milk. The number of $\mathrm{S}$. aureus was $10^{2}-10^{3}$ per $\mathrm{ml}$ after incubation with one per cent of sour milk "Gefilus", Lactobacillus culture or the buttermilk "Kirnupiimä”. The number of $S$. aureus was $10^{7}$ per ml after incubation with one per cent of cooked sour milks "A piimä" or "Gefilus", or in the control tube (Table 1).

\section{Clinical study}

During the study period 11 cases $(6 S$. aureus, 4 Enterococcus faecium and faecalis and 1 coagulase-negative staphylococcus) of new clinical mastitis were recognized (a positive bacterial diagnosis and SCC over 300,000 per $\mathrm{ml}$ of milk). There were 3 cases, 2 cases and 1 case of clinical $S$. aureus IMI during the study in the control, "A piimä" sour milk and iodine groups, respectively.

The decreases in percentages of bacteria-positive milk samples from February to March were statistically significant in relation to all treatments, $(\mathrm{p}<0.001)$. The decreases did not differ significantly between treatments (Table 2 ).

During the treatment period, the smallest proportion of $S$. aureus positive milk samples was found in milk samples from iodine-dipped quarters. The percentage of CNS positive samples was lowest in the "A piimä" sour milk group. Both dipping groups had more Entero-

Table 1. Growth of Staphylococcus aureus inoculated in cooked commercial milk to which had been added various sour milk products.

\begin{tabular}{lcc}
\hline Source & $\begin{array}{c}\text { Bovine blood agar } \\
\text { cells/ml }\end{array}$ & $\begin{array}{c}\text { Bard-Parker agar } \\
\text { cells/ml }\end{array}$ \\
\hline Control & $10 \times 10^{7}$ & $10 \times 10^{7}$ \\
Sour milk "A pumä" & 0 & 0 \\
Cooked "A piimä" & $9 \times 10^{7}$ & $5 \times 10^{7}$ \\
Sour milk "Gefilus" & $3.7 \times 10^{2}$ & $3.3 \times 10^{2}$ \\
Cooked "Gefilus" & $6 \times 10^{7}$ & $6 \times 10^{7}$ \\
Lactobacillus & $2 \times 10^{2}$ & $7 \times 10^{2}$ \\
acidoph1lus culture & $2 \times 10^{2}$ & $1.5 \times 10^{2}$ \\
Buttermılk "Kirnupimä" & & \\
\hline
\end{tabular}


Table 2. Percentage of bacteria positive milk samples.

\begin{tabular}{lcccccc}
\hline Dip group & $\begin{array}{c}\text { Number of } \\
\text { quarters }\end{array}$ & $\begin{array}{c}\text { Start of } \\
\text { dipping } \\
\text { (Feb) }\end{array}$ & March & Aprl & May & June \\
\hline $\begin{array}{l}\text { Control } \\
\text { Sour milk }\end{array}$ & 180 & 18.3 & $6.7^{* * *}$ & 13.3 & 11.1 & 7.8 \\
$+5 \%$ glycerol & 170 & 14.1 & $1.8^{* * *}$ & 12.2 & 10.6 & 7.7 \\
Iodine & 182 & 15.4 & $6.0^{* * *}$ & 13.6 & 12.1 & 9.9 \\
\hline
\end{tabular}

Levels of significance in relation to percentages at start of dipping in February: $* * *=(p<0.001)$.

coccus faecalis and faecium isolations than the control quarters. Percentages of bacterial isolates overall did not differ significantly between treatments $(p=0.291)$ (Table 3$)$.

In cows with $\mathrm{SCC}$ in initial milk samples less than 125,000 , the percentage of quarters with SCC over 125,000 at the end of study was about one third lower in the "A piimä" sour milk group than in the control group, $(16.67 \%$ and $26.23 \%$, respectively, $p=0.074$ ) (Table 4).

\section{Discussion}

In our in vitro study, sour milk containing several species of lactic acid bacteria was effective in inhibiting $S$. aureus growth. We found differences between commercial sour milk products in relation to inhibition of $S$. aureus growth. According to Woodward et al. 1987, ability to inhibit is probably not characteristic of a genus or species but of specific strains of bacteria. The efficacy of any sour milk product should therefore be evaluated in vitro before it is used in practice.

In our clinical study, milk samples were warmed for some minutes to $40^{\circ} \mathrm{C}$ before counting of cells. Warming might have influenced the results of bacterial examination. However, warming was similar for all samples. The percentages of bacteria positive milk samples decreased in all treatment groups one month after the beginning of the study. It is generally accepted that improvement in udder hygiene greatly decrease numbers of bacteria on teat ends (Pankey 1992). It is probable that milking hygiene was better than usual among milkers for some weeks after the beginning of the study.

Because there were only 6 new cases of clinical S. aureus IMI with SCC $>300,000$ during the study, no comparisons between the groups could be analyzed statistically.

In the study reported here, the percentages of $S$. aureus positive milk samples were lowest in the iodine group. The percentages of $S$. aureus or CNS positive milk samples in the sour milk group were lower than those in the control group. This finding is comparable to the findings of Oliver \& Mitchell (1985). In their study, L. acidophilus teat dip preparation was effective against $S$. aureus infections in a commercial dairy herd. However, exact figures are not given in their report.

The decrease in percentage of healthy quarters (low SCC) after May could have been a seasonal effect. Temperature in cowhouses rise towards summer, causing stress and leading to high SCC (Saloniemi 1980). In summer, proper udder hygiene in milking management is apparently more difficult, when cows are on pasture and milked at summer milking stations. It is probable that infection pressure increased in 
Table 3. Percentages of bacteria positıve milk samples during March-June.

\begin{tabular}{lccc}
\hline & \multicolumn{3}{c}{ Treatment group } \\
\cline { 2 - 4 } Bacterial spp & $\begin{array}{c}\text { Control } \\
(712)^{1}\end{array}$ & $\begin{array}{c}\text { Sour milk }+ \\
\text { glycerol (5\%) } \\
(674)\end{array}$ & $\begin{array}{c}\text { Iodine } \\
(722)\end{array}$ \\
\hline Staphylococcus aureus & 3.09 & 2.09 & 0.83 \\
Coagulase-negative staphylococci & 4.07 & 2.52 & 5.26 \\
Streptococcus dysgalactiae & 0.56 & 0.59 & 0.69 \\
Streptococcus uberis $_{\text {Enterococcus faecium } \text { and faecalis }}$ & 0.14 & 0 & 0.97 \\
Other pathogens $^{2}$ & 1.40 & 2.23 & 2.22 \\
Total $^{2}$ & 0.42 & 0.59 & 0.42 \\
& 9.69 & 8.01 & 10.39 \\
\hline
\end{tabular}

${ }^{1}$ Number of quarters.

2 Other streptococci and yeast.

Table 4. Percentage of udder quarters with somatic cell count $>125.000$ cells $/ \mathrm{ml}$ of milk in cows with initial somatic cell count $\leq 125.000$ cells / $\mathrm{ml}$ of milk in all quarters.

\begin{tabular}{lcccccc}
\hline & $\begin{array}{c}\text { Number of } \\
\text { quarters }\end{array}$ & $\begin{array}{c}\text { Start of } \\
\text { dipping } \\
\text { (Feb) }\end{array}$ & March & Aprl & May & June \\
\hline Control & 122 & 0 & 5.74 & 5.08 & 6.56 & 26.23 \\
Sour milk & 114 & 0 & 1.75 & 6.48 & 5.31 & 16.67 \\
Iodine & 124 & 0 & 3.20 & 4.07 & 8.00 & 21.60 \\
\hline
\end{tabular}

group seemed best protected against high SCC levels. Differences between treatments might have been more visible if the study had been continued through the summer. The study reported here was probably stopped too early.

The sour milk dip used in the study reported here included $5 \%$ of glycerol. We did not examine the possible health effect of glycerol on teats. Also the mechanism of how the sour milk affects the teat and udder health was not studied.

Sour milk does not cause a residue problem. Other advantages of sour milk as a post milking teat dip could be that it is easily available as fresh cultures in ordinary shops in many countries, and is cheap.

\section{References}

Gilliland SE, Speck ML. Antagonıstic action of Lactobacillus acidophilus toward intestınal and food borne pathogens in associative cultures. J. Food Prot., 1977, 40, 820-823.

Honkanen-Buzalsk T, Seuna E. Isolation and identıfication of pathogens from milk. In: Sandholm M, Honkanen-Buzalskı T, Kaartınen L, Pyörälä S (eds.). The Bovine Udder and Mastitis. Unıversity of Helsinkı, Faculty of Veterinary Medicine, Helsınk1. 1995, 121-141.

Oliver SP, Mitchell BA - Prevention of bovine mastitts by a Lactobacillus acidophilus preparation. J. Dairy Sci., 1985, Suppl. 1, 68, 271.

Pankey JW: Practical milkıng tıps: pre- and post-dipping. 31 Annual Meeting NMC. 1992, 94-100.

Saloniemi $H \cdot$ Udder diseases in darry cows - field observations on incidence, somatic and environmental factors and control. J. Scient. Agric. Soc. Finland., 1980, 52, 156. 
Woodward WD, Besser TE, Ward ACS, Corbetl LB: In vitro growth inhibition of mastitıs pathogens by bovine teat skin normal flora. Can. J. vet. Res., $1987,51,27-31$.

\section{Sammanfattning}

Inverkan av spendoppning med sur mjölk på uppkomsten av nya juverinflammationer.

I den första studien tillsattes $1 \%$ okokt sur mjölk "A pımä" tıll kokt mjölk. Blandningen förhındrade Staphylococcus aureus tillväxt in vitro. I den följande klinıska studien användes "A piimä" med 5\% glycerol som ett spendoppningsmedel efter mjölknıng från och med februari tıll och med junı. Juverfjärdedel- sprov togs en gång 1 månaden från 133 kor. Bakteriefynd och SCC i mjölkprov från juverfjärdedelar som doppats med sur mjölk jämfördes med dem som doppats med spendoppningsmedel innehållande jod och med dem som inte doppats. Färre $S$ aureus (2.09\%) och CNS (2.52\%) påvisades 1 "surmjolksgruppen" än 1 kontrollgruppen ( $3.09 \%$ och $4.07 \%$, respektıve). I jodgruppen förekom färre $S$ aureus positıva mjölkprov $(0.83 \%)$ men flera CNS positiva mjolkprov (5.26\%) än 1 kontrollgruppen. Skıllnaderna var inte statistiskt signifikanta $(p=0.291)$. Procenten juverfjärdedelar med somatıska celler över 125,000 1 slutet av studien var en tredjedel mindre $\mathrm{i}$ "surmjölksgruppen" än 1 kontrollgruppen ( $16.67 \%$ och $26.23 \%$, $\mathrm{p}=0.074)$. Resultaten indıkerar att surmjölk kan minska uppkomsten av nya juverinflammationer.

(Recelved February 2, 1996; accepted July 30, 1996).

Reprints may be obtaıned from: E. Koskinen, Agricultural Research Centre, Equine Research, Varsanojantie 63, SF-32100 Ypäjä, Finland. Fax: +358 27602 260, e-mail: erkki.koskınen@mtt.fi. 